\title{
Advances and challenges in cancer treatment and nutraceutical prevention: the possible role of dietary phenols in $B R C A$ regulation
}

\author{
Haroon Khan · Fabiana Labanca • Hammad Ullah • Yaseen Hussain • \\ Nikolay T. Tzvetkov $\cdot$ Esra Küpeli Akkol $\cdot$ Luigi Milella $\mathbb{B}$
}

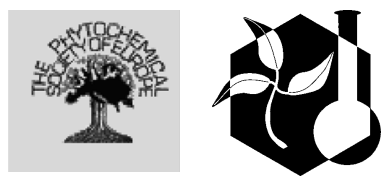

Received: 7 February 2021 / Accepted: 27 July 2021 / Published online: 4 September 2021

(C) The Author(s) 2021

\begin{abstract}
Over the years, the attention towards the role of phytochemicals in dietary natural products in reducing the risk of developing cancer is rising. Cancer is the second primary cause of mortality worldwide. The current therapeutic options for cancer treatment are surgical excision, immunotherapy, chemotherapy, and radiotherapy. Unfortunately, in case of metastases or chemoresistance, the treatment options become very limited. Despite the advances in medical and pharmaceutical sciences, the impact of available treatments on survival is not satisfactory. Recently, natural products are a great deal of interest as potential anti-cancer agents. Among them, phenolic compounds have gained a great deal of interest, thanks to their anti-cancer activity. The present review
\end{abstract}

Haroon Khan and Luigi Milella contributed equally.

\section{H. Khan}

Department of Pharmacy, Abdul Wali Khan University, Mardan 23200, Pakistan

F. Labanca $\cdot$ L. Milella $(\bowtie)$

Department of Sciences, Università della Basilicata, Via dell'Ateneo Lucano, 1085100 Potenza,

PZ, Italy

e-mail: LUIGI.MILELLA@UNIBAS.IT

H. Ullah

Department of Pharmacy, University of Naples Federico

II, Naples, Italy focuses on the suppression of cancer by targeting $B R C A$ gene expression using dietary polyphenols, as well as the clinical aspects of polyphenolic agents in cancer therapy. They regulate specific key processes involved in cancer progression and modulate the expression of oncogenic proteins, like p27, p21, and p53, which may lead to apoptosis, cell cycle arrest, inhibition of cell proliferation, and, consequently, cancer suppression. Thus, one of the mechanisms underlying the anti-cancer activity of phenolics involves the regulation of tumor suppressor genes. Among them, the BRCA genes, with the two forms (BRCA-1 and BRCA-2), play a pivotal role in cancer protection and prevention. $B R C A$ germline mutations are associated with an increased risk of developing several types of cancers, including ovarian, breast, and prostate cancers. BRCA genes also play a key role in

\footnotetext{
Y. Hussain

College of Pharmaceutical Sciences, Soochow University, Suzhou, Jiangsu, China

N. T. Tzvetkov

Institute of Molecular Biology "Roumen Tsanev"

Bulgarian Academy of Sciences (BAS) Acad., G.

Bonchev Str. 21, 1113 Sofia, Bulgaria

E. K. Akkol

Department of Pharmacognosy, Faculty of Pharmacy, Gazi University, 06330 Etiler, Ankara, Turkey
} 
the sensitivity and response of cancer cells to specific pharmacological treatments. As the importance of $B R C A-1$ and $B R C A-2$ in reducing cancer invasiveness, repairing DNA damages, oncosoppression, and cell cycle checkpoint, their regulation by natural molecules has been examined.

Keywords Polyphenols - Cancer - BRCA - Tumor suppressor genes $\cdot$ Clinical aspects

$\begin{array}{ll}\text { Abbreviations } \\ \text { Akt } & \text { Protein kinase B } \\ \text { Bax } & \text { Bcl-2 associated protein } \\ \text { Bak } & \text { Bcl-2 homologous antagonist killer } \\ \text { Bcl-2 } & \text { B-cell lymphoma } 2 \\ B R C A- & \text { Breast cancer type 1 susceptibility protein } \\ 1 & \\ B R C A- & \text { Breast cancer type } 2 \text { susceptibility protein } \\ 2 & \\ \text { COX } & \text { Cyclooxygenase } \\ \text { DSB } & \text { Double strand break } \\ \text { EMT } & \text { Epithelial-mesenchymal transition } \\ \text { ER } & \text { Estrogen receptor } \\ \text { EREs } & \text { Estrogen-responsive elements } \\ \text { HIF-1 } \alpha & \text { Hypoxia inducible factor } \\ \text { IC } 50 & \text { Half minimal inhibitory concentration } \\ \text { IGF-1 } & \text { Insulin like growth factor-1 } \\ \text { MAPK } & \text { Mitogen-activated protein kinase } \\ \text { MMP } & \text { Matrix metallo proteinases } \\ \text { mTOR } & \text { Mammalian target of rapamycin } \\ \text { NF-kB } & \text { Nuclear factor kappa-light-chain enhancer } \\ & \text { of activated B cells } \\ \text { PARP } & \text { Poly ADP-ribose polymerase } \\ \text { PI3K } & \text { Phosphatidylinositide 3-kinases } \\ \text { SIRT1 } & \text { Sirtuin 1 } \\ \text { VEGF } & \text { Vascular endothelial growth factor } \\ & \end{array}$

\section{Introduction}

According to recent statistics published by the World Health Organization (WHO), cancer is the second primary cause of mortality worldwide, accounting for around 9.6 million deaths in 2018 (Kim et al. 2019b). The most common cancers are lung, breast, colorectal, prostate, skin, and stomach cancers. Lung cancer currently possesses the highest mortality rate $(18.4 \%$ of the total cancer deaths), followed by colorectal, stomach, hepatic and female breast cancers (WHO 2019). In addition, 18.7 million new cases have been reported as per statistics compiled by International Agency for Cancer Research (IARC) for the year 2018 (Bray et al. 2018). The sophisticated healthcare and expensive medical treatments make cancer a significant financial burden to the affected families and society (Singh et al. 2015). The WHO estimated the total economic cost of cancer in the year 2010 at approximately 1.16 trillion USD (WHO 2019) and the direct financial cost for cancer in the United States (US) estimated by the Agency for Healthcare Research and Quality (AHRQ) for the year 2015 was around 80.2 billion USD (ACS 2019). The current therapeutic options for the treatment of cancer are surgical excision, immunotherapy, chemotherapy, and radiotherapy. Unfortunately, in the case of metastases, the treatment options become very limited (Kim et al. 2019a). In spite of the advances in the field of medical and pharmaceutical sciences, the impact of available treatments on survival is not satisfactory. On the other hand, data regarding individualized treatment approaches for cancer patients with available therapies is minimal (Crawford et al. 2015). Poor accessibility of anti-cancer agents have been associated with chemotherapy failure and the consequent requirement for high doses of chemotherapeutics, which can cause a range of debilitating side effects, including nausea, vomiting, alopecia, gastrointestinal effects, myelosuppression, immune-suppression, and neuro toxicities (Jang et al. 2003; Khan et al. 2019).

Edible plants contain a number of phytochemicals with the potential for preventing and treating a wide range of disorders, including cancer (Lamorte et al. 2018). The role of polyphenols in reducing cancer is still under discussion. A significant gap occurs between observations in cellular models and the effects of phytochemicals in pre-clinical and clinical models. Natural polyphenols are widely studied for their great potential to prevent and treat cancer of different origins by targeting several molecular pathways (Zhou et al. 2016b). More than 8000 polyphenols, commonly found in vegetables, fruits, cereals, and beverages, have been identified, to date, based on the chemical structures (Lall et al. 2015). Polyphenols are associated with many health benefits, including antioxidant, anti-inflammatory, anti-angiogenic, and anti-proliferative effects (Abdal Dayem et al. 2016). Polyphenols have been reported to arrest the 
development and progression of cancer in some cellular lines, by modulating several signaling pathways, such as nuclear factor-KB (NF-KB) signaling, mitogen activated protein kinases (MAPKs), insulin like growth factor-I (IGF-1) mediated signal transduction pathway, proteasome pathway, vascular endothelial growth factor (VEGF), matrix metalloproteinases (MMP), cyclooxygenase-2 (COX), and breast cancer genes (BRCA) (Khan et al. 2006; Papoutsis et al. 2010; Rowe et al. 2009). BRCA can exist in two forms (BRCA-1 and BRCA-2) and are known as tumor suppressor genes. BRCA germline mutations increase the risk of developing several cancers, including ovarian, breast, and prostate cancers (Fong et al. 2009). BRCA also plays a key role in sensitivity and response of cancer cells to certain treatments such as platinum and pharmacological inhibitors of poly ADPribose polymerase (PARP inhibitors) (Fong et al. 2010). Therapeutic modalities in BRCA mutant carriers are very limited. Surgical treatment has often shown higher survival benefits and less risk with respect to conventional therapies (chemotherapy or radiotherapy) (Ludwig et al. 2016). The current review is designed to focus on the potential of natural polyphenols to modulate $B R C A$ expressions and their outcomes on cancer treatment and prevention.

\section{$B R C A$ in cancers}

BRCA-1 and BRCA-2 proteins play a pivotal role in maintaining genomic stability by enhancing efficient and precise repairing mechanisms of double-strand breaks (DSB) of DNA (Gudmundsdottir and Ashworth 2006). Homologous recombination and non-homologous end joining are the major mechanisms involved in DSB repair (Huertas 2010; Scully et al. 2019). Each 1 and 2 isoforms of the $B R C A$ protein performs several specific homologous recombination repairs. They are associated with a broad range of proteins implicated in the response and repair of DNA damage. It is believed that BRCA-1, being part of a bulky and complex molecule, helps to check DNA double-strand breaks, while BRCA-2 has an important role in the repair of DSBs by involving the recombinase function of RAD51 (Gudmundsdottir and Ashworth 2006; Von Nicolai et al. 2016). So, in a broad framework of repairing mechanisms, both genes act as key components. Therefore, errors or mutations in $B R C A$ genes are associated with a less efficient repair system, leading to an increased risk of developing many types of cancer. In particular, $B R C A-1$ and $B R C A-2$ are crucial in the regulation of repairing processes in breast cells. Indeed epigenetic silencing of these genes often occurs in cancer development (Papoutsis et al. 2010). Thus, they could be defined as "breast cancer susceptibility genes," and inheriting a defective copy of either gene increases an individual's susceptibility to developing breast, ovarian and other types of cancer. Although the role of $B R C A$ in the pathogenesis of cancer is still unclear, significant variations of their expression levels could be detected in cancer cells (Fustier et al. 2003). Being breast and ovarian cancers associated with genetic predisposition, providing a detailed family history may be helpful to healthcare providers in recognizing women at increased risk (Pruthi et al. 2010). These women are more prone to developing second ipsilateral or contralateral breast cancer after diagnosing invasive breast cancer. Also, there is a substantially increased risk of developing ovarian cancer for women with an inherited mutation in either gene (Kotsopoulos 2018; Metcalfe et al. 2011a, b). In the most recent prospective studies, the combined risk of epithelial ovarian cancer up to age 80 was $49 \%$ for BRCA-1 and $21 \%$ for BRCA-2 mutation carriers. These risk estimates are consistent with another report that estimated a cumulative ovarian cancer incidence of $44 \%$ for $B R C A-1$ and $17 \%$ for carriers of BRCA-2 mutations (Kotsopoulos 2018; Kuchenbaecker et al. 2017). About $15 \%$ of all patients with serious ovarian carcinoma have a germline $B R C A$ mutation (Alhuqail et al. 2018). In general, the lifetime risk of developing ovarian cancer is $2 \%$ for females born after 1960 in the United Kingdom (UK) as approximated by Cancer Research UK (Cancer-Research-UK), while breast cancer accounts for $15 \%$ of all new cancer cases in the UK (Cancer-ResearchUK). As regards prostate cancer, it is the most common cancer reported in US men. It is thought to have the highest heritability of any cancer, as confirmed by Scandinavian research suggesting that genetic factors are responsible for up to $57 \%$ of individual risk variation (Hjelmborg et al. 2014), whereas Cancer Research UK reported that 1 in 6 UK males is at lifetime risk for the development of prostate cancer (Cancer-Research-UK). Although some studies have reported that mutations in $B R C A$ 2 are found in just $1.2-3.2 \%$ of prostate cancer patients 
and BRCA-1 mutations in even lower percentages (Giusti et al. 2003), different studies reported that mutations in BRCA are responsible for the increment of prostate cancer rate. In particular, $B R C A-2$ have been associated with a 3- to 8.6-fold increase in risk, approximately, while BRCA-1 mutations increase prostate cancer risk by up to fourfold (Pilarski 2019). Prostate cancers associated with $B R C A-1 / 2$ mutations have been reported to be more aggressive and linked to poorer survival than wild-type $B R C A$ cancers. A study identified 79 prostate cancer patients who carried the BRCA-1/2 mutations and presented impairment in clinical parameters related to cancer progression, as well as a higher Gleason score (approximately 8), higher $\mathrm{T}$ stage (T3/T4), nodal involvement, and metastases (Kote-Jarai et al. 2011; Mitra et al. 2011). Therefore, BRCA-1 and BRCA-2 mutations raise the risk of prostate cancer and contribute to the prevalence of this cancer not only in high-risk families, but also in the general population, in addition to other cancers. Among them, also the development of pancreatic cancer is strictly dependent of $B R C A-1 / 2$ gene mutations. Pancreatic cancer statistics shows that 1 in 53 UK males and 1 in 57 UK females will be diagnosed with pancreatic cancer in their lifetime (CancerResearch-UK). From 3 to $10 \%$ of people with pancreatic adenocarcinoma have a positive family history of pancreatic cancer, and about $10-20 \%$ of pancreatic adenocarcinoma are believed to be due to a hereditary BRCA-1 and BRCA-2 mutation (Petersen 2016). The cumulative chances of developing pancreatic cancer are estimated at 5-10\% for $B R C A-2$ mutation carriers, while mutations in $B R C A-1$ gene contribute to increase the cancer risk by 2-4 times (Salo-Mullen et al. 2015).

Regarding colorectal cancer, the risk conferred by germ line mutations in these two genes is controversial. A longitudinal study on the incidence of colorectal cancer was performed in a cohort study of BRCA-1/ 2 mutation carriers. Results revealed that in females under 50 carrying BRCA-1 mutations, the risk of colorectal cancer is elevated, but not in older women or those carrying BRCA-2 mutations (Phelan et al. 2014). Moreover, a BRCA-related skin cancer study showed that skin cancer risk was correlated with the likelihood of BRCA-1 and BRCA-2 mutations. In the follow-up, of all 1779 women with a BRCA-1 mutation, 29 (1.6\%) developed skin cancer, while out of 950 BRCA-2 mutated women, 28 (3.0\%) developed skin cancer (Ginsburg et al. 2010), suggesting that BRCA-2 mutation carriers are at greater risk of developing skin cancer than BRCA-1 carriers, particularly for basal cell carcinoma.

\section{Polyphenols in cancer: an overview}

Understanding the positive impact of phytochemicals in natural dietary products on the risk of developing cancer still remains an open issue. The major limitations in filling the gap in this context come from the lack of a strong body of knowledge about the pharmacokinetic properties of phenolic compounds in humans. The bioavailability, together with the metabolic reactions, influences the bioactivity of foodderived metabolites. Significant progress needs to be made to clarify the mechanisms of polyphenols in preclinical and clinical models at appropriate and realistic doses. It seems to be realizable due to the numerous in vitro evidence that shed light on the molecular behaviour of phenolic compounds and the involved pathway. Phenolic acids, deriving from benzoic acid, i.e. gallic, vanillic, syringic, and protocatechuic acids, among others, are typically found in nature and have gained a great deal of interest due to the stronger pharmacological properties (Ho et al. 2013). In vitro, indeed, hydroxybenzoic acid and protocatechuic acid exhibited cytotoxic effects towards prostate and breast cancer cells, in a dose-dependent manner (Kassi et al. 2014), while gallic acid displayed inhibitory potential towards HeLa and HTB-35 cervical carcinoma cells, without toxicity on normal cells (Zhao and $\mathrm{Hu} 2013$ ). As one of the hallmarks of cancer is abnormal cell proliferation, phenolic compounds, extracted from plant sources, may prevent cancer cell proliferation (Pandey and Rizvi 2009) and, thus, reduce cancer invasiveness through multiple mechanisms, including apoptosis (Khan et al. 2020b), cell cycle arrest (De Oliveira Niero and Machado-Santelli 2013; Guo et al. 2011), reduction of metalloproteinases, angiogenesis, and cell migration (Zhao and $\mathrm{Hu} 2013$ ).

\section{Apoptosis}

Apoptosis is a well-defined system of programmed cell death that underlies the anti-cancer activity of many phenolic compounds (Armentano et al. 2015; Russo et al. 2018). By increasing the rate of apoptosis 
in cancer cells, natural substances may delay cancer progression. Among polyphenols, phenolic acids have been shown to induce apoptosis: colon cancer cells, treated with $p$-coumaric acid, experienced apoptosis (Sharma et al. 2018). Their activity should be attributed to the activation of apoptotic pathways. The most important are the extrinsic (death receptor pathway), intrinsic (mitochondrial pathway), and the perforin/granzyme apoptotic pathways (Khan et al. 2020b). Whereas the binding of Fas ligand to its proteins activates the extrinsic pathway, the oxidative stress mediates the release of cytochrome-C inside the cells from disrupted mitochondria and triggers the intrinsic pathway (Kim and Kim 2018; Pirzad et al. 2010). The expression of death ligands and receptors is maximized by phenolic compounds through the extrinsic pathway, activating caspases series and intrinsic pathway. The activation of caspases results in DNA damage, cell proliferation inhibition, and apoptosis induction in breast cancers. In this regard, a previous study documented the activation of caspase- 9 when HT-44 cells were processed with cinnamic acid. In turn, this activation leads to potentiate other caspases, including caspases-7 and 3 (De Oliveira Niero and Machado-Santelli 2013). Moreover, caspase activation seems also be implied in the increment of the balance between Bak/Bax (proapoptotic proteins) and Bcl-2 (survival proteins) mediated by polyphenols (Mileo et al. 2012). A separate related study in osteosarcoma cells, indeed, showed that ferulic acid may modulate the balance between oncogenes and oncosuppressor by up-regulating $\mathrm{Bax}$ and down regulating $\mathrm{Bcl}-2$ to induce apoptosis. Likewise, ferulic acid enhanced the expression of Bax, caspase- 3 and 9 in cells of fibrosarcoma (Wang et al. 2016). When breast cancer cells were exposed to 1-(2-hydroxyphenyl)-4-methylpentan-1-one and 2-[(3-methylbutoxy) carbonyl] benzoic acid, two polyphenolic compounds isolated from Himalayan raspberry root extract, elevated levels of caspase-3 and Bax expression were also observed (George and Abrahamse 2019). Protocatechuic acid also increased the levels of caspase-3 and dose-dependently decreased the membrane potential in prostate, hepatic, lung, breast, and cervical cancer cell lines. Likewise, in human HT-1080 fibrosarcoma cell lines, a rise in the caffeic acid concentration corresponded to a proportional boost to apoptosis, with significant changes in the morphology of cells (Jaganathan et al. 2013;
Prasad et al. 2011; Yin et al. 2009). An overview of the main processes engaged in apoptosis under phenolic boost is provided in Fig. 1. Importantly, studies have indicated that polyphenols possess no cytotoxic effects and do not induce apoptosis in normal cells, when compared to breast cancer cell lines (Mileo et al. 2012).

\section{Estrogenic mechanisms}

Phytoestrogens are nonsteroidal plant compounds (plant-derived xenoestrogens) that because of structural resemblance with estradiol possess the ability to cause estrogenic or antiestrogenic effects (Cornwell et al. 2004). They may alter many biological processes, like DNA mutagenesis, apoptosis, cell proliferation, tissue vascularization, and immune response, via estrogen-dependent and -independent mechanisms (Sirotkin and Harrath 2014). Polyphenols, especially phytoestrogens, have shown to be able to inhibit NF$\mathrm{kB}$ and MAPK pathway activation (Miao et al. 2019), which in turn activates the PI3K/Akt/mTOR pathway (Ahmad et al. 2013). This ultimately leads to the synthesis of HIF-1 $\alpha$ that causes MMPs and VEGFs target gene induction in the nucleus. However, efficacy varies between compounds due to differences in their chemical structures and molecular targets, as discussed later.

\section{Cell cycle arrest}

Between phenolic acids, hydroxycinnamic acids have shown great anti-cancer properties. Cinnamic acid, indeed, dose-dependently decreased the viability of the HT-44 melanoma cell lines, with an $\mathrm{IC}_{50}$ value of $2.4 \mathrm{mM}$. One of the proposed mechanisms to explain the cytotoxicity of these compounds is the cell cycle arrest, as occurs in MDA-MB-231 and MCF-7 breast cancer cells, treated with benzoic acid, where the cell cycle arrest is induced at the G2 or M level (De Oliveira Niero and Machado-Santelli 2013; Guo et al. 2011). Likewise, the effectiveness of phenolic compounds in retarding cancer cell proliferation has also been shown in other studies. For example, at an optimal concentration of $1400 \mu \mathrm{mol} / \mathrm{L}$ and $1600 \mu \mathrm{mol} /$ $\mathrm{L}$ respectively, $p$-coumaric acid reduced the viability of HCT-15 and HT-29 colorectal cells (Jaganathan et al. 2013). Similarly, $p$-coumaric acid and ferulic acid were shown to suppress the MIA-Pa-Ca-22 


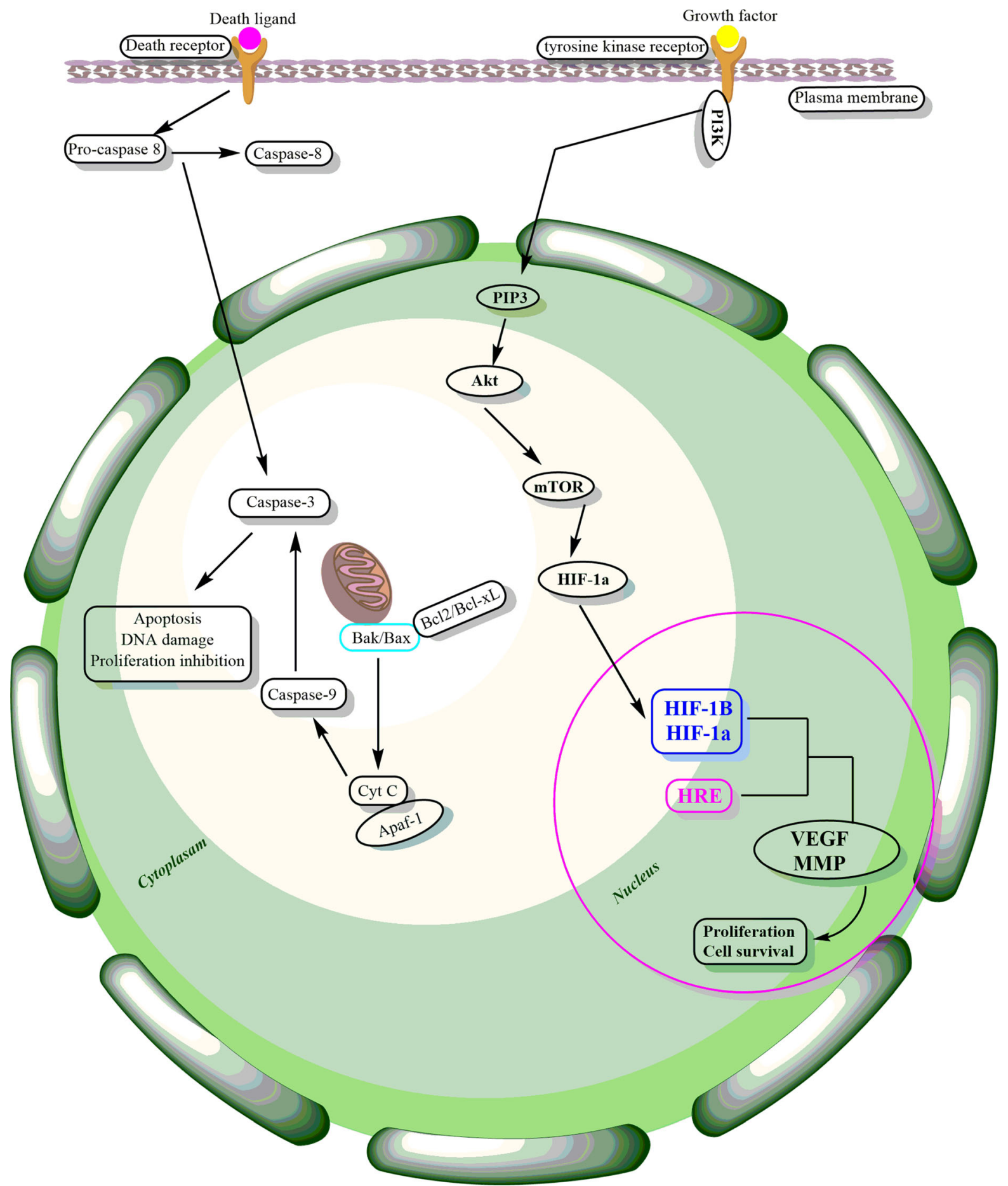

pancreatic cancer cell line (Fahrioğlu et al. 2016). Likewise, caffeic and 5-caffeoylquinic acids reduced the cell lines viability of HT-29 colorectal carcinoma and HT-1080 fibrosarcoma cells by modifying the cell cycle stage and increasing the apoptotic rate (Murad et al. 2015; Prasad et al. 2011). 
4Fig.1 General model of phenols targeting $B R C A$ via various pathway modulations. The main mechanism involves apoptosis which is conducted via intrinsic and extrinsic pathways. During extrinsic pathway, death ligand and receptor expression is maximized through phenolic compounds activation of caspases and intrinsic pathway, Bak/Bax (proapoptotic proteins) are increase along with reduction of $\mathrm{Bcl}-2$ followed by caspase activation via phenols. Phenols, especially phytoestrogens, avoid NF-kB and MAPK pathway activation which in turn activates PI3K/Akt/mTOR pathway indirectly. This ultimately leads to HIF-1 $\alpha$ synthesis into the nucleus that is responsible of MMPs and VEGFs target gene induction. The activation of caspases results in DNA damage, inhibition of cell proliferation and induction of apoptosis in breast cancers. Apaf- 1 apoptosis activating factor-1; $B c l-2$ B cell lymphoma $2 ; B c l-x L$ B cell lymphoma extra-large; $H I F-1 \alpha$ hypoxia-inducible factor; $H R E$ hypoxia-responsive element; $m T O R$ mammalian target of rapamycin; $M M P$ matrix metalloprotease; $P I 3 K$ phosphatidylinositol 3-kinase; PIP3 phosphatidylinositol

\section{Cell migration and invasion}

Migration and invasion of tumor cells are tactics formed and implemented by cancer cells to proliferate in other districts and avoid drug therapy (Clark and Vignjevic 2015). The PI3K/Akt/mTOR signaling pathway plays a key role in cancer invasiveness due to its involvement in cell growth and the metabolism of cancer cells. The activation of NF- $\kappa \mathrm{B}$ downstream signaling cascade leads to the final synthesis of HIF$1 \alpha$. Once entered into the nucleus, it causes MMPs and VEGFs gene induction, enhancing angiogenesis and metastases (Ahmad et al. 2013). This may explain why finding natural molecules that can target this pathway could reveal as an alternative therapeutic option for fighting cancer. Many biologically active phenolic compounds extracted from plants are known to interrupt cell migration by interfering with epithelial-mesenchymal transition, cell invasion, and efflux. For example, in breast cancer cell lines, ferulic acid reduced metastasis by reversing the epithelial-mesenchymal transition (Zhang et al. 2016). By blocking the voltage-gated sodium channels, caffeic acid phenyl esters stopped the proliferation of non-small cell lung, colon, and breast cancer cell lines (Fraser et al. 2016), while gallic acid inhibited metastasis in gastric cancer cells via downregulating PI3K/Akt pathway (Mao et al. 2020). The whole scheme of the multiple mechanisms at the basis of phenolic anticancer activity is shown in Fig. 2.

\section{Polyphenols targeting $B R C A$ in cancer}

Phytoestrogens are natural bioactive compounds that exert anti-cancer, antiproliferative, and chemopreventive effects through different mechanisms. Many of them are flavonoids, but also coumestans, and resorcylic acid lactones display estrogenic properties (Gehm et al. 1997). As the importance of BRCA-1 and $B R C A-2$ in reducing cancer invasiveness, repairing DNA damages, oncosuppression, and cell cycle checkpoint (Nabavi et al. 2018), their regulation by natural molecules has been recently examined (Rowe et al. 2009).

Genetic and epigenetic regulation on BRCA genes by polyphenols

Epigenetic modifications are the major mechanisms for modulating gene expression. Demethylation and acetylation of histones by phytochemicals allow chromatin to be unpacked, enhancing the transcription of genes involved in cancer. Flavanols intrude on the transmethylation pathway, limiting the availability of S-adenosylmethionine, leading to changes in DNA methylation (Khan et al. 2020a; Vanden Berghe 2012). Consistently with reported evidence, a possible approach to tumor chemoprevention is to reverse unfavorable epigenetic marks by natural dietary polyphenols. A great source of polyphenols is constituted by pomegranate. Extracts from peel, seeds, and juice of pomegranate might inhibit cancer cell growth, inducing $\mathrm{G}_{2} / \mathrm{M}$ cell cycle arrest and apoptosis, and prevent tumorigenesis in a dose- and time-dependent manner. Molecular mechanisms which underlie these properties involved the DNA repairing pathway, including $B R C A-1$ and $B R C A-2$ downregulation in MCF-7 cancer cells (Shirode et al. 2013).

\section{Resveratrol}

Resveratrol (3,5,4'-trihydroxystilbene) is a naturally occurring phytoalexin, widely detectable among berries, grapes, and peanuts, which is produced in response to various biotic and abiotic stresses. It can bind the estrogen receptors (ERs) and regulates the transcription of estrogen-responsive target genes, as well as $B R C A-1$ and $B R C A-2$, in two ways: by direct bonding to the estrogen-responsive element (EREs) on DNA or by interaction with transcription factors 


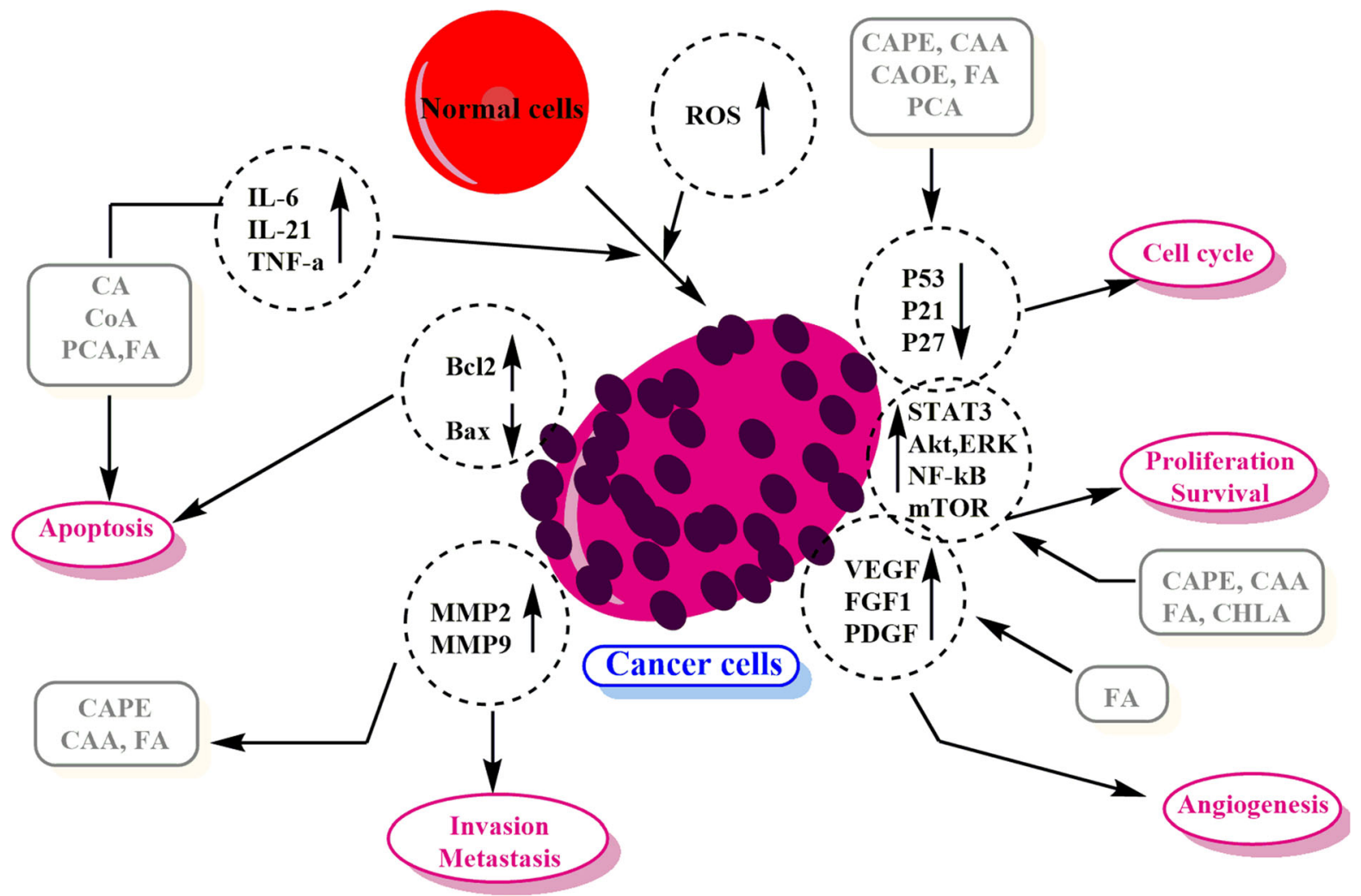

Fig. 2 Phenolic anticancer activity via multiple pathways modulation. Phenolic compounds regulate certain key processes associated with the progression of cancer. They may modulate the expression of genes involved in cell proliferation, apoptosis and cell cycle arrest. $A K T$ protein kinase B; $B c l-2$ B-cell lymphoma-2; $C A$ caffeic acid; $C A A$ cellular antioxidants activities; $C A O E$ caffeoylquinic esters; $C A P E$ Caffeic acid

(Fustier et al. 2003). It could be due to the structuresimilarity to endogenous ligand, the estradiol, since both molecules have a phenolic ring and two hydroxyls (Gehm et al. 1997; Vissac-Sabatier et al. 2003), as shown in Fig. 3. Interestingly, even if resveratrol binds $\operatorname{ER} \alpha$ and ER $\beta$ with the same affinity, it can induce transcription better than endogenous ligand in ER $\beta$, indicating that it may exert a stronger oestrogenic activity in ER $\beta$ expressing cells respect ER $\alpha$ (Bowers et al. 2000). In human breast cancer cells, resveratrol $(3-10 \mu \mathrm{M})$ competes for estrogen receptors binding, showing inhibitory activity towards the binding of estradiol to its estrogen receptor, while activating the transcription of estrogen-responsive genes (Gehm et al. 1997). The increased transcription of $p S 2$ gene, a marker of estrogen receptor pathway activation, confirms the phytoestrogenic activity of phenethyl ester; $E R K$ extracellular signal regulated kinases; $F A$ ferulic acid; $F G F-1$ fibroblast growth factor-1; $M M P 2$ matrix metalloproteinase-2; $M M P 9$ matrix metalloproteinase-9; $N F-k B$ Nuclear Factor kappa-light-chain-enhancer of activated B cells; $P D G F$ platelet derived growth factor; ROS reactive oxygen species; STAT3 signal transducer and activator of transcription3; VEGF vascular endothelial factor

resveratrol (Le Corre et al. 2004). In some cancer lines (i.e. MCF-7 cells), resveratrol behaves as a superagonist, with a higher transcriptional response than estradiol, while in others, it has an estradiol-comparable activity. It may depend on the type of ER and the ERE sequence involved (Gehm et al. 1997). The treatment with resveratrol $(30 \mu \mathrm{m})$ on MCF7, HBL100, and MDA-MB-231 human breast cancer cell lines results in an increment from two- to four-fold of BRCA-1 and BRCA-2 mRNA. Inconsistently, no increments were detected at protein level, implying the occurrence of unknown post-transcriptional events (Fustier et al. 2003). Resveratrol doses of 30-50 $\mu \mathrm{M}$ increase not only BRCA-1 and BRCA-2 expression, but also a panel of genes that regulate and interplay with $B R C A-1$ in human breast cell lines, as well as $p 53$, RAD51, p21 $1^{\text {wafl/cipl }}, C B P / P 300, K i 67$, and $p S 2$ (Le 


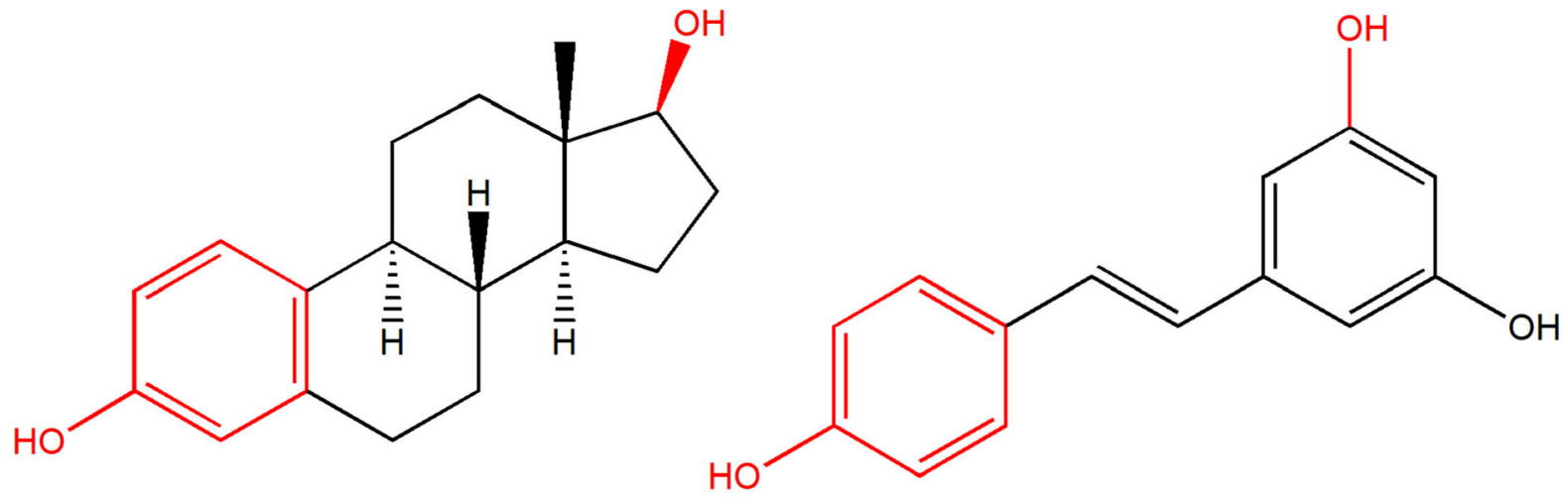

\section{Estradiol}

\section{Resveratrol}

Fig. 3 Resveratrol competes with estradiol for estrogen receptor binding thanks to the structure-similarity (portions in common are highlighted in red)

Corre et al. 2004). Resveratrol treatment is a potential strategy to possibly reduce $B R C A-1$ mutant tumor growth both in vitro and in vivo, by up-regulating its downstream mediator SIRT-1, which leads to survivin under expression. As SIRT-1 possesses an important role in the DNA damage repairing process, and survivin is an anti-apoptotic protein and is often over-expressed in several tumors, it is believed that the proapoptotic activity of resveratrol is expounded through the SIRT-1 modulation (Wang et al. 2008). Finally, although the resveratrol bioavailability is influenced by different factors, as well as a rapid and extensive intestinal and hepatic metabolism that reduces it to less than $1 \%$ (Sergides et al. 2016), this phytoalexin may be seen as a conditioner of BRCArelated breast cancer. In general, polyphenol fraction in wine, including resveratrol, has shown BRCA modulating properties (Hakimuddin et al. 2008). Additional regulatory effects of resveratrol work via the antagonism on the aromatic hydrocarbon receptor, which activation is led to higher proneness to mammary and intestinal cancer development (Papoutsis et al. 2010). As this pathway is involved in xenobiotic metabolism and detoxification processes, it is activated by different environmental toxins, as well as dioxins, promoting the expression of oncogenes and proinflammatory cytokines and the repression of oncosuppressors through epigenetic modifications. Activated aromatic hydrocarbon receptor is recruited to the BRCA-1 promoter where inhibits estradiolmediated BRCA-1 transcription. Furthermore, resveratrol pretreatment $(1 \mu \mathrm{mol} / \mathrm{L})$ also attenuates the suppression of BRCA-1 gene expression, caused by dioxins exposure, by reversing $B R C A-1$ hypermethylation (Papoutsis et al. 2012). In MCF-7 breast cancer cells, resveratrol not only decreases the binding of aromatic hydrocarbon receptor on $B R C A-1$ promoter by $60 \%$, but also promotes estrogen-dependent $B R C A$ 1 expression through the agonism on estrogen receptors (Papoutsis et al. 2010). Resveratrol competitively displaces dioxins from binding site, acting as antagonist towards aromatic hydrocarbon receptor (Macpherson and Matthews 2010).

\section{Flavonoids}

As activated aromatic hydrocarbon receptor possesses a promiscuous binding site for many food-derived bioactive molecules, many officinal herb or foodderived compounds could act as antagonists, providing higher cancer prevention (Lamorte et al. 2020). They include polyphenols, most of all flavonoids, but also carotenoids, as lutein and lycopene from carrots and tomatoes, and indoles, as indole-3-carbinol from cruciferous vegetables (Busbee et al. 2013; Xue et al. 2017). Among flavonoids, kaempferol (3,4',5,7-tetrahydroxyflavone) (Macpherson and Matthews 2010) and quercetin (Ciolino et al. 1999), two flavonols commonly present in green leafy vegetables and onions, share with resveratrol the ability to competitively displaces dioxins from the binding site, acting as an antagonist towards aromatic hydrocarbon receptor. In human leukemia HL-60 cells, kaempferol induces cell apoptosis through DNA damage and DNA 
repair inhibition by suppressing the expression of DNA repairing proteins, including BRCA-1 (Wu et al. 2015). Also, kaempferol $(20-54.7 \mu \mathrm{M})$ reduces EJ bladder cancer cells growth by up to $8 \%$, while it is associated with high safety on SV-HUC-1 healthy bladder cells. Cancer growth is inhibited by promoting BRCA-1 phosphorylation, leading to apoptosis and $\mathrm{G}_{1}$ / S phase cell cycle arrest (Deng 2006; Wu et al. 2018). Curcumin from turmeric and tangeritin from tangerine and citrus peels have been found to interact with the activated aromatic hydrocarbon receptor (Ciolino et al. 1998). Moreover, the combination of curcumin, the main component of Curcuma longa L. rhizome, and quercetin increased the BRCA-1 expression in triple-negative breast cancer cell lines by enhancing histone $\mathrm{H} 3 \mathrm{~K} 9$ acetylation on its promoter region. In $B R C A-1$ knockdown cell lines that are more prone to cancer development, the treatment with the two molecules is able to inhibit tumor spread through modulation of tumor suppressor genes (Kundur et al. 2019). This evidence highlights the importance of synergism among different natural molecules. The concept of synergy is at the basis of Traditional Chinese Medicine, where the complex synergistic interactions in the herbal formulations are believed to enhance the bioavailability of active components, promote therapeutic effects, and reduce toxicity. Nowadays, the "one drug, one target, one disease" paradigm, indeed, appears dated and it is progressively being replaced by combined therapeutic approaches, including multiple bioactive components with higher efficacy and less side effects. Many studies have demonstrated that whole plant extracts show greater efficacy when compared with corresponding doses of individual active ingredients (Zhou et al. 2016a), driving the researchers to investigate further different combinations. Thus, the effect of quercetin and curcumin has been assessed, showing that taken together, they might help to bypass cisplatin resistance (Arzuman et al. 2014). Furthermore, curcumin demonstrated chemosensitizing properties towards cisplatinresistant A549 lung cells. By suppressing the FA/ $B R C A$ pathway, the repairing mechanisms are inhibited, allowing cisplatin to be more effective (Chen et al. 2015). This is what is commonly described as synthetic lethality. When $B R C A$ is mutated, adaptative mechanisms induce cells to exploit other repairing systems. Some phytochemicals revealed able to modulate their expression, leading cells to death. In BRCA-
2 deficient-tumors, curcumin is also able to target another repairing system, involving RAD52. In this way, it prevents double-strand break repair, enhancing the effectiveness of current chemotherapic drugs (Wang et al. 2015). Also, curcumin dose-dependently reduces the toxicity due to several pollutants' exposure, as well as heterocyclic amines. In breast epithelial cells (MCF 10A), indeed, $150 \mu \mathrm{M}$ of curcumin is associated with an increment of viability by up $100 \%$. The decrease of BRCA-1 expression, associated with curcumin treatment, seems to be due to the prevention of double strand breaks and the related repairing processes (Jain et al. 2015). The expression of BRCA-1 and $B R C A-2$ was inhibited also in MDA-MB-231 breast cells by curcumin. In particular, curcumin nanoparticles $(68.5 \mu \mathrm{g} / \mathrm{mL})$ showed a stronger inhibitory power rather than free curcumin $(40 \mu \mathrm{mol})$. This inhibition seems to be related to the ability of curcumin nanoparticles to reduce p300/CBP activity, a regulator of repairing processes that modulate the expression of related genes, including BRCA (Meena et al. 2017). In triple-negative breast cancer, curcumin exerts antiproliferative activity, while no cytotoxic effects have been reported after curcumin treatment in non-cancer breast cells (MCF12A) (Rowe et al. 2009). This evidence solves the question about gene aspecificity for epigenetic modifications by curcumin, raised by Dagdemir et al. (2013), showing that it targets only cancer-related genes.

\section{Isoflavones}

In MCF-7 and MDA-MB 231 breast cancer cell line, the cancer development is inhibited by some soy isoflavones, most of all equol $(12.8 \mu \mathrm{M})$, genistein $(18.5 \mu \mathrm{M})$, suberoylanilide hydroxamic acid $(1 \mu \mathrm{M})$, and daidzein $(78.5 \mu \mathrm{M})$. On the basis of their activity, there are epigenetic modifications aimed to demethylate and acetylate $B R C A$ histones to promote repairing events (Dagdemir et al. 2013). Moreover, in combination with indole-3-carbinol, genistein can promote $B R C A-1$ and BRCA-2 expression greater than alone, confirming the importance of synergic effects. By using siRNA, Fan et al. (2006) demonstrated that $B R C A-2$ induction mostly depends on $B R C A-1$, but not viceversa. In MCF-7 and T47D breast and DU-145 and $\mathrm{LNCaP}$ prostate tumor cell lines, the increase of $B R C A-1$ and $B R C A-2$ plays a pivotal role in cytotoxicity induction. 
In conclusion, phytoestrogen-rich foods contain a combination of different elements which form the phytocomplex. Many studies reported that the entire phytocomplex is more active than the single components (Ettorre et al. 2010) and the bioactivity may be not ascribed only to the most abundant compounds but to the synergism between molecules found both in high and low concentrations (Nanni et al. 2020). Although the specific composition of the phytocomplex in a plant may vary depending on growth conditions and environmental influences, the different components, working in synergy, may represent a potential chemopreventive and antiproliferative cocktail against cancer (Nanni et al. 2020). Therefore, the consumption of fruits and vegetables is related to a decreased risk of cancer, especially breast cancer, thanks to the ability to affect gene expression, including BRCA (Hakimuddin et al. 2008) and modulate aberrant epigenetic processes, including histone modification, DNA methylation, and non-coding RNA (miRNA) alteration, on a chromosomal level. Epigenetic changes are promising molecular targets for breast cancer prevention and treatment, considering their impact on endocrine, autocrine and paracrine pathways (Pan et al. 2014). An overview of the main polyphenols targeting $B R C A$ is provided in Fig. 4.

\section{Clinical aspects}

The majority of breast cancers are sporadic forms, but in the $5-7 \%$ of the cases they are associated with hereditary mutations on BRCA-1 and BRCA-2 genes. Women carrying BRCA-1 mutations have a $65 \%$ possibility of developing breast cancer, while the risk decreases to $40 \%$ if they carry BRCA-2 mutations (Van der Groep et al. 2006). External factors seem to considerably influence the risk of developing hereditary breast and ovarian cancer (Ghadirian et al. 2009). Many natural phenolic compounds with phytoestrogen potential have been suggested as a possible therapeutic approach to reduce breast cancer risk (Pan et al. 2014), mainly in BRCA mutation carriers (Ghadirian et al. 2009). During repairing processes and cellular proliferation that follow the ovulation, indeed, they seem to provide a defense system against DNA-damage, thanks to the high content of folate and vitamins. Despite this, no studies are currently available on different dietary interventions on $B R C A$ mutationbearing women. Most literature evidence reports a positive correlation between high fruit and vegetable intake and cancer decrease, but the joint effects of BRCA mutations and varied diets have received very little attention. Only a French-Canadian

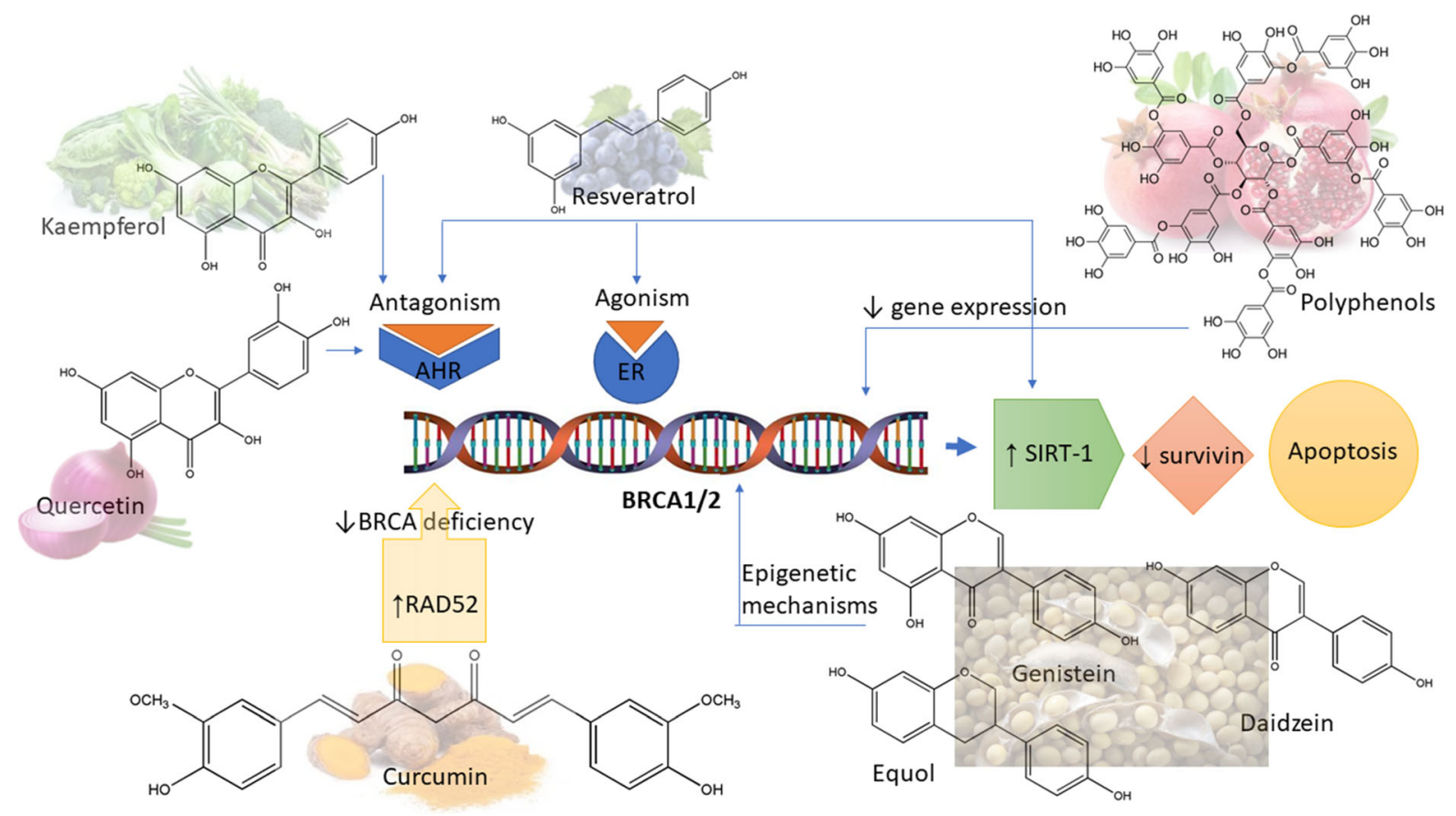

Fig. 4 Overview of main natural phenolic compounds targeting $B R C A$ genes 
epidemiological investigation, including 738 women subjected to genetic tests for BRCA mutations, revealed a significant correlation among $B R C A$ mutations and vegetable and fruit intake (case-only odds ratio $=0.27$ ) (Ghadirian et al. 2009).

Although the precise mechanism at the basis of polyphenol activity is still under discussion, it appears clear that these types of dietary patterns have a precious role in cancer chemoprevention, showing a correlation with mutations of $B R C A$-dependent breast cancers (Ghadirian et al. 2009).

\section{Conclusion}

Nature is a rich source of phytochemicals with potential therapeutic effects that may be considered a preventative or possibly complementary therapeutic strategy in treating numerous chronic disorders. Thanks to the molecular promiscuity and character diversity acquired through evolution, many polyphenols of vegetable origin have demonstrated pleiotropic therapeutic properties against a wide range of pathological conditions, including different kinds of cancers. As pleiotropic effects of synthetic drugs are unpredictable, as they include others than those specifically planned, pleiotropic compounds are often avoided in drug development. However, pleiotropic effects may be not only negative (toxicity or adverse effects) but also beneficial, as is the case of beneficial cardiovascular effects of statins (Davignon 2004). Further, much evidence have demonstrated that bioactive phytochemicals possess pleiotropic effects that are beneficial and in high demand in the context of multifactorial diseases, like cancer (Gunesch et al. 2020). Many studies revealed that polyphenols might modulate signaling pathways involved in cancer and affect the expression of oncogenic proteins, holding cancer preventing effects (Shehzad et al. 2020). BRCA genes play an important part in preventing cancers and associated mutations, reducing the chances of developing malignant tumors. The available therapeutic modalities in BRCA mutant carriers are limited, e.g., tamoxifen is currently prescribed as prophylaxis. However, health care providers and patients often rely on chemotherapy, radiotherapy, or surgical therapy, with all related side effects. Up-regulating $B R C A$ genes by polyphenols might be a potential alternative therapeutic strategy in the management of cancer.
However, current clinical evidence regarding the modulation of BRCA genes by polyphenols in cancer is very limited. Further pre-clinical and clinical studies should be highly encouraged in this regard.

Open Access This article is licensed under a Creative Commons Attribution 4.0 International License, which permits use, sharing, adaptation, distribution and reproduction in any medium or format, as long as you give appropriate credit to the original author(s) and the source, provide a link to the Creative Commons licence, and indicate if changes were made. The images or other third party material in this article are included in the article's Creative Commons licence, unless indicated otherwise in a credit line to the material. If material is not included in the article's Creative Commons licence and your intended use is not permitted by statutory regulation or exceeds the permitted use, you will need to obtain permission directly from the copyright holder. To view a copy of this licence, visit http://creativecommons.org/licenses/by/4.0/.Funding Open access funding provided by Università degli Studi della Basilicata within the CRUI-CARE Agreement.

\section{References}

Abdal Dayem A, Choi H, Yang G-M, Kim K, Saha S, Cho S-G (2016) The anti-cancer effect of polyphenols against breast cancer and cancer stem cells: molecular mechanisms. Nutrients 8:581

ACS (2019) Economic impact of cancer. vol. 2019.

Ahmad A, Biersack B, Li Y, Kong D, Bao B, Schobert R, Padhye BS, Sarkar HF (2013) Targeted regulation of PI3K/ Akt/mTOR/NF- $\kappa B$ signaling by indole compounds and their derivatives: mechanistic details and biological implications for cancer therapy. anti-Cancer Agents in Medicinal Chemistry (Formerly Current Medicinal Chemistry-Anti-Cancer Agents) 13, 1002-1013.

Alhuqail A-J, Alzahrani A, Almubarak H, Al-Qadheeb S, Alghofaili L, Almoghrabi N, Alhussaini H, Park BH, Colak D, Karakas B (2018) High prevalence of deleterious BRCA-1 and BRCA-2 germline mutations in arab breast and ovarian cancer patients. Breast Cancer Res Treat 168:695-702

Armentano MF, Bisaccia F, Miglionico R, Russo D, Nolfi N, Carmosino M, Andrade PB, Valentao P, Diop MS, Milella L (2015) Antioxidant and proapoptotic activities of sclerocarya birrea [(A. Rich.) Hochst.] methanolic root extract on the hepatocellular carcinoma cell line HepG2. Biomed Res Int 2015:561589

Arzuman L, Beale P, Chan C, Yu JQ, Huq F (2014) Synergism from combinations of tris(benzimidazole) monochloroplatinum(II) Chloride with Capsaicin, Quercetin, Curcumin and Cisplatin in human ovarian cancer cell lines. Anticancer Res 34:5453-5464

Bowers JL, Tyulmenkov VV, Jernigan SC, Klinge CM (2000) Resveratrol acts as a mixed agonist/antagonist for estrogen receptors $\alpha$ and $\beta$. Endocrinology 141:3657-3667

Bray F, Ferlay J, Soerjomataram I, Siegel RL, Torre LA, Jemal A (2018) Global cancer statistics 2018: GLOBOCAN 
estimates of incidence and mortality worldwide for 36 cancers in 185 countries. CA: A Cancer J Clin 68:394-424

Cancer-Research-UK, Breast cancer statistics. vol. 2021.

Busbee PB, Rouse M, Nagarkatti M, Nagarkatti PS (2013) Use of natural AhR ligands as potential therapeutic modalities against inflammatory disorders. Nutr Rev 71:353-369

Chen P, Li J, Jiang H-G, Lan T, Chen Y-C (2015) Curcumin reverses cisplatin resistance in cisplatin-resistant lung cancer cells by inhibiting FA/BRCA pathway. Tumor Biol 36:3591-3599

Ciolino HP, Daschner PJ, Wang TT, Yeh GC (1998) Effect of curcumin on the aryl hydrocarbon receptor and cytochrome P450 1A1 in MCF-7 human breast carcinoma cells. Biochem Pharmacol 56:197-206

Ciolino HP, Daschner PJ, Yeh GC (1999) Dietary flavonols quercetin and kaempferol are ligands of the aryl hydrocarbon receptor that affect CYP1A1 transcription differentially. Biochem J 340:715-722

Clark AG, Vignjevic DM (2015) Modes of cancer cell invasion and the role of the microenvironment. Curr Opin Cell Biol $36: 13-22$

Cornwell T, Cohick W, Raskin I (2004) Dietary phytoestrogens and health. Phytochemistry 65:995-1016

Crawford ED, Higano CS, Shore ND, Hussain M, Petrylak DP (2015) Treating patients with metastatic castration resistant prostate cancer: a comprehensive review of available therapies. J Urol 194:1537-1547

Dagdemir A, Durif J, Ngollo M, Bignon Y-J, Bernard-Gallon D (2013) Histone lysine trimethylation or acetylation can be modulated by phytoestrogen, estrogen or anti-HDAC in breast cancer cell lines. Epigenomics 5:51-63

Davignon J (2004) Beneficial cardiovascular pleiotropic effects of statins. Circulation 109:III-39-III-43

De Oliveira Niero EL, Machado-Santelli GM (2013) Cinnamic acid induces apoptotic cell death and cytoskeleton disruption in human melanoma cells. J Exp Clin Cancer Res $32: 31$

Deng CX (2006) BRCA-1: cell cycle checkpoint, genetic instability, DNA damage response and cancer evolution. Nucleic Acids Res 34:1416-1426

Ettorre A, Frosali S, Andreassi M, Di Stefano A (2010) Lycopene phytocomplex, but not pure lycopene, is able to trigger apoptosis and improve the efficacy of photodynamic therapy in HL60 human leukemia cells. Exp Biol Med 235:1114-1125

Fahrioğlu U, Dodurga Y, Elmas L, Seçme M (2016) Ferulic acid decreases cell viability and colony formation while inhibiting migration of MIA $\mathrm{PaCa}-2$ human pancreatic cancer cells in vitro. Gene 576:476-482

Fan S, Meng Q, Auborn K, Carter T, Rosen EM (2006) BRCA-1 and $B R C A-2$ as molecular targets for phytochemicals indole-3-carbinol and genistein in breast and prostate cancer cells. Br J Cancer 94:407-426

Fong PC, Boss DS, Yap TA, Tutt A, Wu P, Mergui-Roelvink M, Mortimer P, Swaisland H, Lau A, O'Connor MJ (2009) Inhibition of poly (ADP-ribose) polymerase in tumors from BRCA mutation carriers. N Engl J Med 361:123-134

Fong PC, Yap TA, Boss DS, Carden CP, Mergui-Roelvink M, Gourley C, De Greve J, Lubinski J, Shanley S, Messiou C (2010) Poly (ADP)-ribose polymerase inhibition: frequent durable responses in $B R C A$ carrier ovarian cancer correlating with platinum-free interval. J Clin Oncol 28:2512-2519

Fraser SP, Hemsley F, Djamgoz MB (2016) Caffeic acid phenethyl ester: Inhibition of metastatic cell behaviours via voltage-gated sodium channel in human breast cancer in vitro. Int J Biochem Cell Biol 71:111-118

Fustier P, Le Corre L, Chalabi N, Vissac-Sabatier C, Communal Y, Bignon YJ, Bernard-Gallon DJ (2003) Resveratrol increases BRCA-1 and BRCA-2 mRNA expression in breast tumour cell lines. Br J Cancer 89:168-172

Gehm BD, McAndrews JM, Chien P-Y, Jameson JL (1997) Resveratrol, a polyphenolic compound found in grapes and wine, is an agonist for the estrogen receptor. Proc Natl Acad Sci 94:14138-14143

George BP, Abrahamse H (2019) Increased oxidative stress induced by rubus bioactive compounds induce apoptotic cell death in human breast cancer cells. Oxidative Med Cell Longev

Ghadirian P, Narod S, Fafard E, Costa M, Robidoux A, Nkondjock A (2009) Breast cancer risk in relation to the joint effect of BRCA mutations and diet diversity. Breast Cancer Res Treat 117:417-422

Ginsburg OM, Kim-Sing C, Foulkes WD, Ghadirian P, Lynch HT, Sun P, Narod SA, Group, H. B. C. C. S (2010) BRCA-1 and $B R C A-2$ families and the risk of skin cancer. Fam Cancer 9:489-493

Giusti R, Rutter J, Duray P, Freedman L, Konichezky M, FisherFischbein J, Greene M, Maslansky B, Fischbein A, Gruber S (2003) A twofold increase in BRCA mutation related prostate cancer among Ashkenazi Israelis is not associated with distinctive histopathology. J Med Genet 40:787-792

Gudmundsdottir K, Ashworth A (2006) The roles of BRCA-1 and BRCA-2 and associated proteins in the maintenance of genomic stability. Oncogene 25:5864-5874

Gunesch S, Hoffmann M, Kiermeier C, Fischer W, Pinto AF, Maurice T, Maher P, Decker M (2020) 7-O-Esters of taxifolin with pronounced and overadditive effects in neuroprotection, anti-neuroinflammation, and amelioration of short-term memory impairment in vivo. Redox Biol 29:101378

Guo H, Li M, Chen P, Blake DJ, Kong X, Hao X, Niu R, Zhang N (2011) 4-Methyl-3-nitro-benzoic acid, a migration inhibitor, prevents breast cancer metastasis in SCID mice. Cancer Lett 305:69-75

Hakimuddin F, Tiwari K, Paliyath G, Meckling K (2008) Grape and wine polyphenols down-regulate the expression of signal transduction genes and inhibit the growth of estrogen receptor-negative MDA-MB231 tumors in $\mathrm{nu} / \mathrm{nu}$ mouse xenografts. Nutr Res 28:702-713

Hjelmborg JB, Scheike T, Holst K, Skytthe A, Penney KL, Graff RE, Pukkala E, Christensen K, Adami H-O, Holm NV (2014) The heritability of prostate cancer in the Nordic Twin Study of Cancer. Cancer Epidemiol Prev Biomark 23:2303-2310

Ho H-H, Chang C-S, Ho W-C, Liao S-Y, Lin W-L, Wang C-J (2013) Gallic acid inhibits gastric cancer cells metastasis and invasive growth via increased expression of RhoB, downregulation of AKT/small GTPase signals and inhibition of NF- $\kappa \mathrm{B}$ activity. Toxicol Appl Pharmacol 266:76-85 
Huertas P (2010) DNA resection in eukaryotes: deciding how to fix the break. Nat Struct Mol Biol 17:11-16

Jaganathan SK, Supriyanto E, Mandal M (2013) Events associated with apoptotic effect of p-Coumaric acid in HCT-15 colon cancer cells. World J Gastroenterol: WJG 19:7726

Jain A, Samykutty A, Jackson C, Browning D, Bollag WB, Thangaraju M, Takahashi S, Singh SR (2015) Curcumin inhibits PhIP induced cytotoxicity in breast epithelial cells through multiple molecular targets. Cancer Lett 365:122-131

Jang SH, Wientjes MG, Lu D, Au JL-S (2003) Drug delivery and transport to solid tumors. Pharm Res 20:1337-1350

Kassi E, Chinou I, Spilioti E, Tsiapara A, Graikou K, Karabournioti S, Manoussakis M, Moutsatsou P (2014) A monoterpene, unique component of thyme honeys, induces apoptosis in prostate cancer cells via inhibition of NF-Kb activity and IL-6 secretion. Phytomedicine 21:1483-1489

Khan N, Afaq F, Saleem M, Ahmad N, Mukhtar H (2006) Targeting multiple signaling pathways by green tea polyphenol (-)-epigallocatechin-3-gallate. Can Res 66:2500-2505

Khan H, Ullah H, Martorell M, Valdes SE, Belwal T, Tejada S, Sureda A, Kamal MA (2019) Flavonoids nanoparticles in cancer: treatment, prevention and clinical prospects. Seminars in cancer biology. Elsevier

Khan H, Belwal T, Efferth T, Farooqi AA, Sanches-Silva A, Vacca RA, Nabavi SF, Khan F, Prasad Devkota H, Barreca D (2020a) Targeting epigenetics in cancer: therapeutic potential of flavonoids. Crit Rev Food Sci Nutr 61:1-24

Khan H, Reale M, Ullah H, Sureda A, Tejada S, Wang Y, Zhang Z-J, Xiao J (2020b) Anti-cancer effects of polyphenols via targeting p53 signaling pathway: Updates and future directions. Biotechnol Adv 38:107

Kim C, Kim B (2018) Anti-cancer natural products and their bioactive compounds inducing ER stress-mediated apoptosis: a review. Nutrients 10:1021

Kim DH, Khan H, Ullah H, Hassan ST, Šmejkal K, Efferth T, Mahamoodally MF, Xu S, Habtemariam S, Filosa R (2019a) MicroRNA targeting by quercetin in cancer treatment and chemoprotection. Pharmacol Res 147:104346

Kim DH, Khan H, Ullah H, Hassan ST, Šmejkal K, Efferth T, Mahomoodally MF, Xu S, Habtemariam S, Filosa R (2019b) MicroRNA targeting by quercetin in cancer treatment and chemoprotection. Pharmacol Res 147:104346

Kote-Jarai Z, Leongamornlert D, Saunders E, Tymrakiewicz M, Castro E, Mahmud N, Guy M, Edwards S, O’brien, L., Sawyer, E., (2011) BRCA-2 is a moderate penetrance gene contributing to young-onset prostate cancer: implications for genetic testing in prostate cancer patients. $\mathrm{Br} \mathrm{J}$ Cancer 105:1230-1234

Kotsopoulos J (2018) BRCA mutations and breast cancer prevention. Cancers 10:524

Kuchenbaecker KB, Hopper JL, Barnes DR, Phillips K-A, Mooij TM, Roos-Blom M-J, Jervis S, Van Leeuwen FE, Milne RL, Andrieu N (2017) Risks of breast, ovarian, and contralateral breast cancer for BRCA-1 and BRCA-2 mutation carriers. JAMA 317:2402-2416

Kundur S, Prayag A, Selvakumar P, Nguyen H, McKee L, Cruz C, Srinivasan A, Shoyele S, Lakshmikuttyamma A (2019)
Synergistic anticancer action of quercetin and curcumin against triple-negative breast cancer cell lines. J Cell Physiol 234:11103-11118

Lall R, Syed D, Adhami V, Khan M, Mukhtar H (2015) Dietary polyphenols in prevention and treatment of prostate cancer. Int J Mol Sci 16:3350-3376

Lamorte D, Faraone I, Laurenzana I, Milella L, Trino S, De Luca L, Del Vecchio L, Armentano MF, Sinisgalli C, Chiummiento L (2018) Future in the Past: Azorella glabra Wedd. as a source of new natural compounds with antiproliferative and cytotoxic activity on multiple myeloma cells. Int $\mathrm{J}$ Mol Sci 19:33

Lamorte D, Faraone I, Laurenzana I, Trino S, Russo D, Rai DK, Armentano MF, Musto P, Sgambato A, De Luca L, Milella L, Caivano A (2020) Advances in Azorella glabra Wedd. Extract research: in vitro antioxidant activity, antiproliferative effects on acute myeloid leukemia cells and bioactive compound characterization. Molecules 25:4890

Le Corre L, Fustier P, Chalabi N, Bignon YJ, Bernard-Gallon D (2004) Effects of resveratrol on the expression of a panel of genes interacting with the BRCA-1 oncosuppressor in human breast cell lines. Int J Clin Chem 344:115-121

Ludwig KK, Neuner J, Butler A, Geurts JL, Kong AL (2016) Risk reduction and survival benefit of prophylactic surgery in BRCA mutation carriers, a systematic review. Am J Surg 212:660-669

Macpherson L, Matthews J (2010) Inhibition of aryl hydrocarbon receptor-dependent transcription by resveratrol or kaempferol is independent of estrogen receptor alpha expression in human breast cancer cells. Cancer Lett 299:119-129

Mao Q-Q, Xu X-Y, Shang A, Gan R-Y, Wu D-T, Atanasov AG, Li H-B (2020) Phytochemicals for the prevention and treatment of gastric cancer: Effects and mechanisms. Int $\mathrm{J}$ Mol Sci 21:570

Meena R, Kumar S, Kumar R, Gaharwar US, Rajamani P (2017) PLGA-CTAB curcumin nanoparticles: Fabrication, characterization and molecular basis of anticancer activity in triple negative breast cancer cell lines (MDA-MB-231 cells). Biomed Pharmacother 94:944-954

Metcalfe K, Gershman S, Lynch HT, Ghadirian P, Tung N, KimSing C, Olopade O, Domchek S, McLennan J, Eisen A (2011a) Predictors of contralateral breast cancer in BRCA1 and $B R C A-2$ mutation carriers. $\mathrm{Br} \mathrm{J}$ Cancer 104:1384-1392

Metcalfe K, Lynch HT, Ghadirian P, Tung N, Kim-Sing C, Olopade OI, Domchek S, Eisen A, Foulkes WD, Rosen B (2011b) Risk of ipsilateral breast cancer in BRCA-1 and BRCA-2 mutation carriers. Breast Cancer Res Treat 127:287-296

Miao L, Tao H, Peng Y, Wang S, Zhong Z, El-Seedi H, Dragan S, Zengin G, San Cheang W, Wang Y (2019) The antiinflammatory potential of Portulaca oleracea L. (purslane)

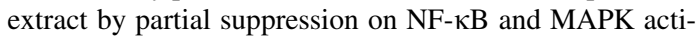
vation. Food Chem 290:239-245

Mileo AM, Di Venere D, Linsalata V, Fraioli R, Miccadei S (2012) Artichoke polyphenols induce apoptosis and decrease the invasive potential of the human breast cancer cell line MDA-MB231. J Cell Physiol 227:3301-3309

Mitra AV, Bancroft EK, Barbachano Y, Page EC, Foster C, Jameson C, Mitchell G, Lindeman G, Stapleton A, Suthers 
G (2011) Targeted prostate cancer screening in men with mutations in BRCA-1 and BRCA-2 detects aggressive prostate cancer: preliminary analysis of the results of the IMPACT study. BJU Int 107:28-39

Murad LD, Soares NDCP, Brand C, Monteiro MC, Teodoro AJ (2015) Effects of caffeic and 5-caffeoylquinic acids on cell viability and cellular uptake in human colon adenocarcinoma cells. Nutr Cancer 67:532-542

Nabavi SF, Atanasov AG, Khan H, Barreca D, Trombetta D, Testai L, Sureda A, Tejada S, Vacca RA, Pittala V, Gulei D, Berindan-Neagoe I, Shirooie S, Nabavi SM (2018) Targeting ubiquitin-proteasome pathway by natural, in particular polyphenols, anticancer agents: Lessons learned from clinical trials. Cancer Lett 434:101-113

Nanni V, Di Marco G, Sacchetti G, Canini A, Gismondi A (2020) Oregano phytocomplex induces programmed cell death in melanoma lines via mitochondria and DNA damage. Foods 9:1486

Cancer-Research-UK, Ovarian cancer statistics. vol. 2021.

Pan MH, Chiou YS, Chen LH, Ho CT (2014) Breast cancer chemoprevention by dietary natural phenolic compounds: specific epigenetic related molecular targets. Mol Nutr Food Res 59:21-35

Cancer-Research-UK, Pancreatic cancer statistics. vol. 2021.

Pandey KB, Rizvi SI (2009) Plant polyphenols as dietary antioxidants in human health and disease. Oxidative Med Cell Longev 2:270-278

Papoutsis AJ, Lamore SD, Wondrak GT, Selmin OI, Romagnolo DF (2010) Resveratrol prevents epigenetic silencing of BRCA-1 by the aromatic hydrocarbon receptor in human breast cancer cells. J Nutr 140:1607-1614

Papoutsis AJ, Borg JL, Selmin OI, Romagnolo DF (2012) BRCA-1 promoter hypermethylation and silencing induced by the aromatic hydrocarbon receptor-ligand TCDD are prevented by resveratrol in MCF-7 cells. J Nutr Biochem 23:1324-1332

Petersen GM (2016) Familial pancreatic cancer. Seminars in oncology, vol 43. Elsevier, pp 548-553

Phelan C, Iqbal J, Lynch HT, Lubinski J, Gronwald J, Moller P, Ghadirian P, Foulkes W, Armel S, Eisen A (2014) Incidence of colorectal cancer in BRCA-1 and BRCA-2 mutation carriers: results from a follow-up study. $\mathrm{Br} \mathrm{J}$ Cancer 110:530-534

Pilarski R (2019) The role of BRCA testing in hereditary pancreatic and prostate cancer families. Am Soc Clin Oncol Educ Book 39:79-86

Pirzad G, Jafari M, Tavana S, Sadrayee H, Ghavami S, Shajiei A, Ghanei M (2010) The role of Fas-FasL signaling pathway in induction of apoptosis in patients with sulfur mustard-induced chronic bronchiolitis. J Toxicol 2010:373612

Prasad NR, Karthikeyan A, Karthikeyan S, Reddy BV (2011) Inhibitory effect of caffeic acid on cancer cell proliferation by oxidative mechanism in human HT-1080 fibrosarcoma cell line. Mol Cell Biochem 349:11-19

Cancer-Research-UK, Prostate cancer statistics. vol. 2021.

Pruthi S, Gostout BS, Lindor NM (2010) Identification and management of women with BRCA mutations or hereditary predisposition for breast and ovarian cancer. Mayo Clinic proceedings, vol 85. Elsevier, Amsterdam, pp 1111-1120
Rowe DL, Ozbay T, O'Regan RM, Nahta R (2009) Modulation of the BRCA-1 protein and induction of apoptosis in triple negative breast cancer cell lines by the polyphenolic compound curcumin. Breast Cancer: Basic Clin Res 3, BCBCR. S3067.

Russo D, Miglionico R, Carmosino M, Bisaccia F, Andrade PB, Valentao P, Milella L, Armentano MF (2018) A comparative study on phytochemical profiles and biological activities of Sclerocarya birrea (A.Rich.) Hochst Leaf and bark extracts. Int J Mol Sci 19:186

Salo-Mullen EE, O'Reilly EM, Kelsen DP, Ashraf AM, Lowery MA, Yu KH, Reidy DL, Epstein AS, Lincoln A, Saldia A (2015) Identification of germline genetic mutations in patients with pancreatic cancer. Cancer 121:4382-4388

Scully R, Panday A, Elango R, Willis NA (2019) DNA doublestrand break repair-pathway choice in somatic mammalian cells. Nat Rev Mol Cell Biol 20:698-714

Sergides C, Chirilă M, Silvestro L, Pitta D, Pittas A (2016) Bioavailability and safety study of resveratrol $500 \mathrm{mg}$ tablets in healthy male and female volunteers. Exp Ther Med 11:164-170

Sharma SH, Rajamanickam V, Nagarajan S (2018) Antiproliferative effect of p-Coumaric acid targets UPR activation by downregulating Grp78 in colon cancer. Chem Biol Interact 291:16-28

Shehzad A, Ul Islam S, Al-Suhaimi EA, Lee Y (2020) Pleiotropic effects of bioactive phytochemicals (polyphenols and terpenes). Functional foods, nutraceuticals and natural products. DEStech Publications Inc., Lancaster, PA, USA.

Shirode AB, Kovvuru P, Chittur SV, Henning SM, Heber D, Reliene R (2013) Antiproliferative effects of pomegranate extract in MCF-7 breast cancer cells are associated with reduced DNA repair gene expression and induction of double strand breaks. Mol Carcinog 53:458-470

Singh CK, Ndiaye MA, Ahmad N (2015) Resveratrol and cancer: Challenges for clinical translation. Biochim Biophys Acta (BBA) Mol Basis Dis 1852:1178-1185

Sirotkin AV, Harrath AH (2014) Phytoestrogens and their effects. Eur J Pharmacol 741:230-236

Van der Groep P, Bouter A, van der Zanden R, Siccama I, Menko FH, Gille JJ, van Kalken C, van der Wall E, Verheijen RH, van Diest PJ (2006) Distinction between hereditary and sporadic breast cancer on the basis of clinicopathological data. J Clin Pathol 59:611-617

Vanden Berghe W (2012) Epigenetic impact of dietary polyphenols in cancer chemoprevention: lifelong remodeling of our epigenomes. Pharmacol Res 65:565-576

Vissac-Sabatier C, Coxam V, Déchelotte P, Picherit C, Horcajada M-N, Davicco M-J, Lebecque P, Bignon Y-J, BernardGallon D (2003) Phytoestrogen-rich diets modulate expression of BRCA-1 and BRCA-2 tumor suppressor genes in mammary glands of female Wistar rats. Can Res 63:6607-6612

Von Nicolai C, Ehlén Å, Martin C, Zhang X, Carreira A (2016) A second DNA binding site in human $B R C A-2$ promotes homologous recombination. Nat Commun 7:1-8

Wang RH, Zheng Y, Kim HS, Xu X, Cao L, Luhasen T, Lee MH, Xiao C, Vassilopoulos A, Chen W, Gardner K, Man YG, Hung MC, Finkel T, Deng CX (2008) Interplay among BRCA-1, SIRT1, and Survivin during BRCA-1-associated tumorigenesis. Mol Cell 32:11-20 
Wang SH, Lin PY, Chiu YC, Huang JS, Kuo YT, Wu JC, Chen CC (2015) Curcumin-Mediated HDAC Inhibition Suppresses the DNA Damage Response and Contributes to Increased DNA Damage Sensitivity. PLoS ONE 10:e0134110

Wang T, Gong X, Jiang R, Li H, Du W, Kuang G (2016) Ferulic acid inhibits proliferation and promotes apoptosis via blockage of PI3K/Akt pathway in osteosarcoma cell. Am J Transl Res 8:968

WHO (2019) Cancer-key facts, vol 2019. World Health Organization

Wu LY, Lu HF, Chou YC, Shih YL, Bau DT, Chen JC, Hsu SC, Chung JG (2015) Kaempferol induces DNA damage and inhibits DNA repair associated protein expressions in human promyelocytic leukemia HL-60 cells. Am J Chin Med 43:365-382

Wu P, Meng X, Zheng H, Zeng Q, Chen T, Wang W, Zhang X, Su J (2018) Kaempferol attenuates ROS-induced hemolysis and the molecular mechanism of its induction of apoptosis on bladder cancer. Molecules 23:2592

Xue Z, Li D, Yu W, Zhang Q, Hou X, He Y, Kou X (2017) Mechanisms and therapeutic prospects of polyphenols as modulators of the aryl hydrocarbon receptor. Food Funct 8:1414-1437
Yin M-C, Lin C-C, Wu H-C, Tsao S-M, Hsu C-K (2009) Apoptotic effects of protocatechuic acid in human breast, lung, liver, cervix, and prostate cancer cells: potential mechanisms of action. J Agric Food Chem 57:6468-6473

Zhang X, Lin D, Jiang R, Li H, Wan J, Li H (2016) Ferulic acid exerts antitumor activity and inhibits metastasis in breast cancer cells by regulating epithelial to mesenchymal transition. Oncol Rep 36:271-278

Zhao B, Hu M (2013) Gallic acid reduces cell viability, proliferation, invasion and angiogenesis in human cervical cancer cells. Oncol Lett 6:1749-1755

Zhou X, Seto SW, Chang D, Kiat H, Razmovski-Naumovski V, Chan K, Bensoussan A (2016a) Synergistic effects of Chinese herbal medicine: a comprehensive review of methodology and current research. Front Pharmacol 7:201

Zhou Y, Zheng J, Li Y, Xu D-P, Li S, Chen Y-M, Li H-B (2016b) Natural polyphenols for prevention and treatment of cancer. Nutrients 8:515-522

Publisher's Note Springer Nature remains neutral with regard to jurisdictional claims in published maps and institutional affiliations. 